\title{
Soils and Fertilizers for Master Gardeners: Soil Physical Characteristics $^{1}$
}

\author{
Amy L. Shober, Alexander J. Reisinger, Mary G. Lusk, and Sally Ann Scalera²
}

\section{Introduction}

Soils are a foundational component of the landscape. Soils provide a medium for plant root growth and are crucial for nutrient cycling and water movement across the landscape. Furthermore, soils can act as a natural filter, helping to remove excess nutrients and other contaminants before these pollutants reach sensitive surface waters (lakes, rivers, oceans) or groundwater. In this article, we will describe the physical properties of soils, including soil formation in Florida, the soil profile, and water dynamics within soils. This article is intended to provide a thorough reference for Master Gardeners and other individuals who are searching for a fundamental, basic understanding of soil dynamics to be applied to residential landscapes. An improved understanding of these physical characteristics will allow the Master Gardener to make informed management choices to maintain a healthy residential landscape.

\section{Soil Formation in Florida}

The state of Florida is located on the Floridian plateau, a broad and fairly flat landform separating the Atlantic Ocean from the Gulf of Mexico. Changes in sea level throughout geological history lead to the deposition of marine sediments on the plateau. Many of these sediments are composed of the fossilized remains of marine organisms that died and sank to the ocean floor. Over millions of years, the shells of these organisms were compacted and formed into layers of white carbonate rock, known as limestone. The karst topography common to Florida, including sinkholes, caves and springs (karst features), is formed by this limestone geology dissolving.

\section{Factors Impacting Soil Formation}

Soil scientists recognize five driving factors that interact to form our soils: 1) parent material, 2) climate, 3) topography, 4) biological activity, and 5) time.

Parent material is the rock or other material from which the soil is derived. Soils often form directly from the rocks beneath them as the bedrock breaks down over time.

This situation is not common in Florida, though, with the exception of some calcareous (calcium-carbonate rich, chalky) soils in Miami-Dade County (for more information about calcareous soils, see EDIS publication SL183, Calcareous Soils in Miami-Dade County, at http://edis. ifas.ufl.edu/TR004). Soils can also form from materials transported from another location via wind or water. Many of Florida's sandy soils were formed directly from sandy marine sediments, which were transported and deposited by ocean currents. In contrast to the sandy soils prevalent throughout much of the state, Florida's organic-rich soils

1. This document is SL451, one of a series of the Department of Soil and Water Sciences, UF/IFAS Extension. Original publication date July 2019. This document combines and supersedes SL260/MG445, SL268/MG451, SL272/MG453, and SL274/MG455. Visit the EDIS website at https://edis.ifas.ufl.edu for the currently supported version of this publication.

2. Amy L. Shober, former associate professor, Center for Landscape Conservation and Ecology, Department of Soil and Water Sciences, UF/IFAS Gulf Coast Research and Education Center; Alexander J. Reisinger, assistant professor, Department of Soil and Water Sciences, Center for Landscape Conservation and Ecology; Mary G. Lusk, assistant professor, Department of Soil and Water Sciences, UF/IFAS Gulf Coast REC; and Sally Ann Scalera, urban horticulture agent, UF/IFAS Extension Brevard County; UF/IFAS Extension, Gainesville, FL 32611.

The Institute of Food and Agricultural Sciences (IFAS) is an Equal Opportunity Institution authorized to provide research, educational information and other services

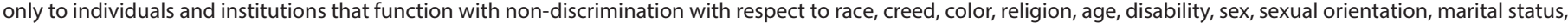
national origin, political opinions or affiliations. For more information on obtaining other UF/IFAS Extension publications, contact your county's UF/IFAS Extension office. U.S. Department of Agriculture, UF/IFAS Extension Service, University of Florida, IFAS, Florida A \& M University Cooperative Extension Program, and Boards of County Commissioners Cooperating. Nick T. Place, dean for UF/IFAS Extension. 
developed from decaying swamp and marsh plants, where flooded conditions prevented complete decomposition of these materials. Clay-rich soils of the panhandle and upland ridges were formed from materials that eroded from the Appalachian Mountains and the southern coastal plain, which were then transported southward by rivers.

Climate impacts soil formation in multiple ways. Temperature and moisture regimes affect the weathering (breakdown) rate of parent material, with weathering typically being more rapid under the warm, wet conditions common in Florida. These conditions also accelerate the decomposition of soil organic material, which is why Florida's sandy soils are typically lower in organic matter than soils of the northeastern or midwestern United States, where the climate is humid but cooler.

The elevation and slope of the land (topography) affects soil formation by changing drainage patterns, erosion rates, and vegetation types. Soils formed on ridges are typically well drained and more prone to erosion than soils formed where the land surface is relatively flat. Low-lying areas with poor drainage often exhibit an accumulation of organic matter and/or clay particles, allowing the formation of organic-rich soils.

The activity of animals, plants, and microorganisms (biology) also plays a role in soil formation. For example, the burrowing of some animals physically mixes the soil, whereas microbial decomposition degrades organic material and incorporates some of these materials into the soil. Many other properties of the soil are influenced by vegetation, and vice versa. For example, as leaves fall from trees they will be broken down by microbial activity, affecting the $\mathrm{pH}$, organic matter content, and nutrient availability of the soil.

The final factor responsible for soil formation is time. The formation of a soil is a complex process that takes a very long time. Each of the previously identified factors (parent material, climate, topography, and biological activity) act on soil formation processes at different timescales, but it takes a long time for parent material to be broken down. For example, Floridian soils are relatively young compared to other areas of the United States. The fluctuation of sea levels that have periodically inundated much of the state have left little time for mature soil profiles to develop. The degree of soil development varies widely throughout the state. For example, the Entisol soils (Figure 1) dominant throughout the central Florida Ridge have had little time to develop the characteristic profiles (see the next section for an in-depth description of soil profiles) of older soils such as the Ultisols of the north Florida panhandle (Figure 2). It can take hundreds to thousands of years for deep, fertile soil to develop.

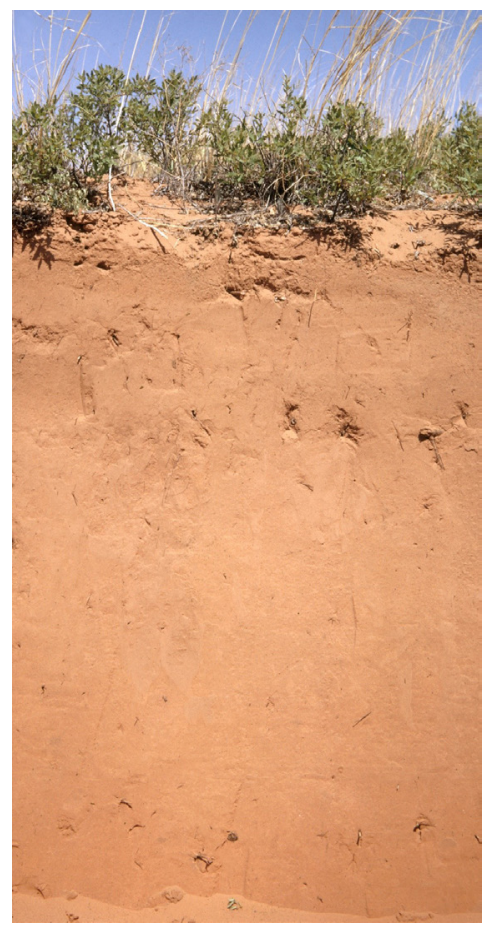

Figure 1. Entisol soil profile. Credits: NRCS-USDA

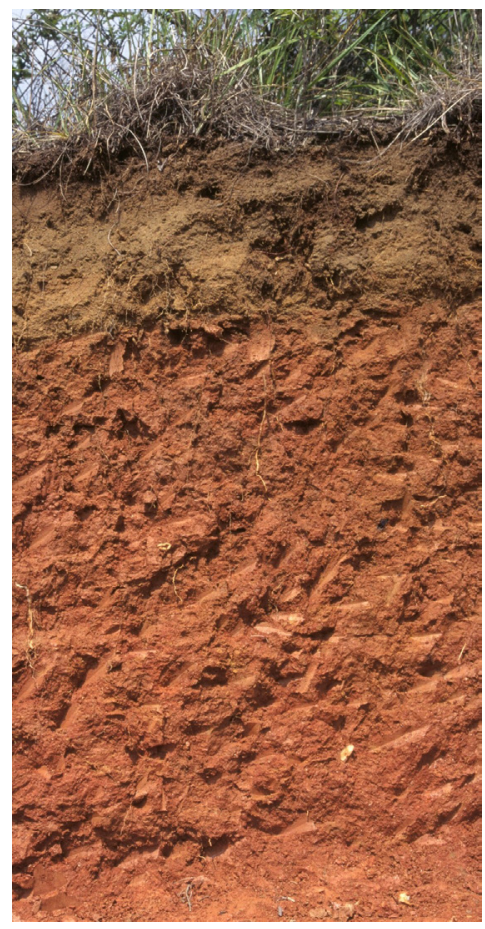

Figure 2. Ultisol soil profile. Credits: NRCS-USDA 


\section{The Soil Profile and Soil Classification}

Soils are made up of layers called horizons, which can be seen when a vertical section of the soil is exposed. The properties of individual soil horizons vary as a result of the factors discussed above. The combination of these soil horizons provides the soil profile (Figure 3). Undisturbed soils will exhibit one or more of the following horizons (in vertical order of appearance, starting with the surface):

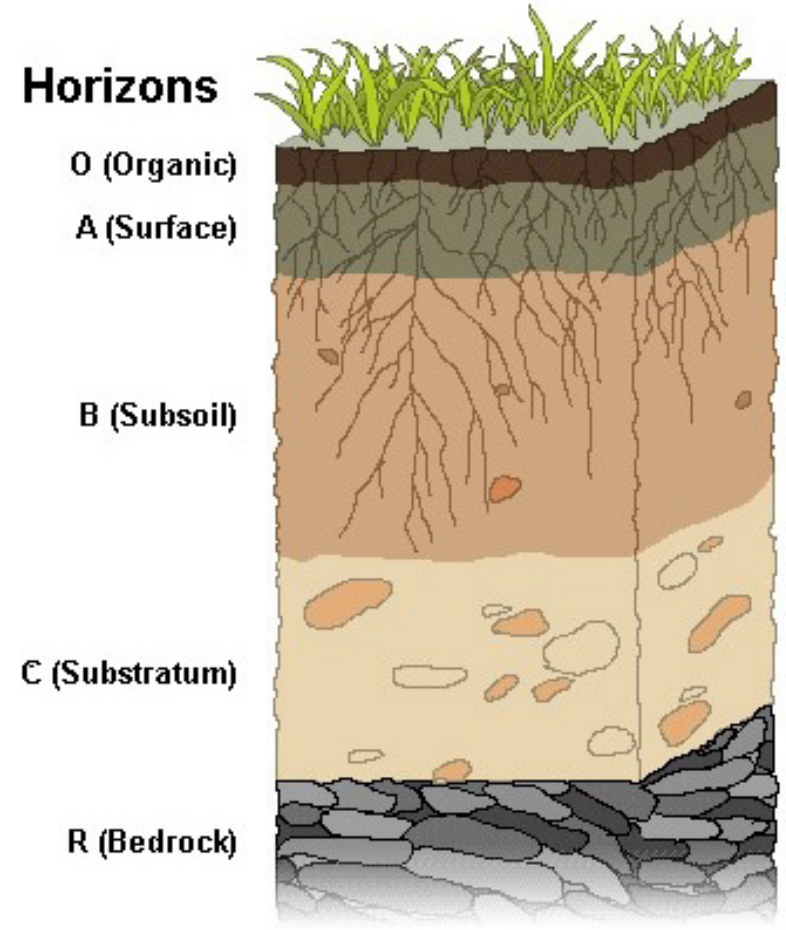

Figure 3. The soil profile.

Credits: Wikipedia Commons

O horizon: The O horizon consists of the surface accumulation of organic materials (plant or animal residues) in various stages of decomposition. Freshly deposited materials are found at the surface of the soil and can be identified as coming from a specific plant or animal (e.g., pine needles, animal waste). More decomposed materials are found underneath the freshly deposited materials and are often not distinguishable as specific materials; instead they appear as rich, darkly colored organic material.

A horizon: The A horizon is the surface soil horizon consisting of mineral soil material enriched with organic matter. As a result of this organic matter, the A horizon is often dark in color. The A horizon is commonly referred to as the topsoil and typically consists of the most fertile soil. Increasing the amount of organic matter in the A horizon of residential landscapes can improve physical properties, reduce irrigation demand, and improve soil fertility.
E horizon: The E horizon is a relatively light-colored soil horizon that may be found just below the A horizon. Organic matter and/or clay and iron have leached out of this horizon (moved downward), giving this horizon its light color. The E horizon is common in soils formed under pine forest vegetation and may look similar to sandbox sand.

$B$ horizon: The $\mathrm{B}$ horizon is characterized by an accumulation of organic matter, clay, or other minerals that have been transported from surface horizons or formed in place as a result of chemical and physical processes. Soil in this horizon is typically referred to as subsoil.

C horizon: The $\mathrm{C}$ horizon is the least developed of the soil horizons and often represents the parent material from which the soil was formed. Soil in the $\mathrm{C}$ horizon has been impacted to a small extent by chemical and physical forces. Soil in this horizon is also part of the subsoil.

$R$ horizon: The $\mathrm{R}$ horizon consists of bedrock material ( $\mathrm{R}$ stands for "rock"). This material, if found, is usually the material from which the soil formed as a result of physical and chemical weathering.

Just as animals, plants, and insects are broken down into orders, families, genera, and species, soils are classified based on physical, chemical, and biological properties. Unlike plant or animal classification, soil classification systems differ across countries. Here we focus on the US classification system, which is a hierarchical system with six categories. Soil order is the broadest category used to describe soils based on the presence or absence of specific soil properties in surface or subsurface horizons. There are twelve distinct soil orders located throughout the world, seven of which are found in Florida. For more information on the soil orders of Florida, see the EDIS Publications SL43, Key to Soil Orders in FL (http://ufdc.ufl.edu/IR00003421/00001), and SL441, Agricultural Soils of Florida (http://edis.ifas.ufl. edu/ss655). The Myakka soil series is Florida's official state soil, its name originating from a Native American term for "big waters." Soil series descriptors are available from the USDA NRCS at: https://www.nrcs.usda.gov/wps/portal/ $\mathrm{nrcs} /$ detail/soils/survey/class/data/?cid=nrcs142p2_053587.

\section{Physical Properties of Soil}

A soil is a three-dimensional material comprised of solids, liquids, and gases and occurring on the land surface. Soils typically consist of approximately $45 \%$ mineral material, $5 \%$ (or less) organic material, and 50\% pore space, which is occupied by air and/or water. Most Floridian soils have low 
organic material, typically much less than $5 \%$. The mineral fraction of soil is made up of particles falling into three different size classes: sand (0.05-2.0 mm diameter), silt $(0.002-0.05 \mathrm{~mm})$, and clay $(<0.002 \mathrm{~mm})$. When discussing soil physical properties, the terms sand, silt, and clay are based on the absolute size of the particles, not the specific minerals that make up the particles. As particle size decreases, the influence of an individual particle on nutrientand water-holding properties of the soil increases. Smaller particles have more surface area available to interact with nutrients and can be packed into an area more tightly than larger particles, potentially reducing water movement through soils. The specific minerals that individual particles are made up of can also affect the nutrients available and other chemical and physical properties of soils. For example, because they are dominated by quartz, many clay-sized particles in Florida have fairly low reactivity with nutrients.

\section{Soil Texture}

The term soil texture refers to the relative proportion of sand, silt, and clay particles in a soil. Soils can either be sandy (dominated by sand-sized particles), clayey (dominated by clay-sized particles), or loamy (dominated by silt-sized particles). Soil texture can be further broken down into 12 different textures based upon their sand, silt, and clay content and defined by the soil textural triangle (Figure 4). In Florida, surface soils tend to fall in the sandy, loamy sand, or sandy loam textural classes located in the bottom left-hand corner of the textural triangle. Knowing the texture of your soil can provide information to the Master Gardener about important soil physical properties such as soil water-holding capacity (discussed below) and soil fertility.

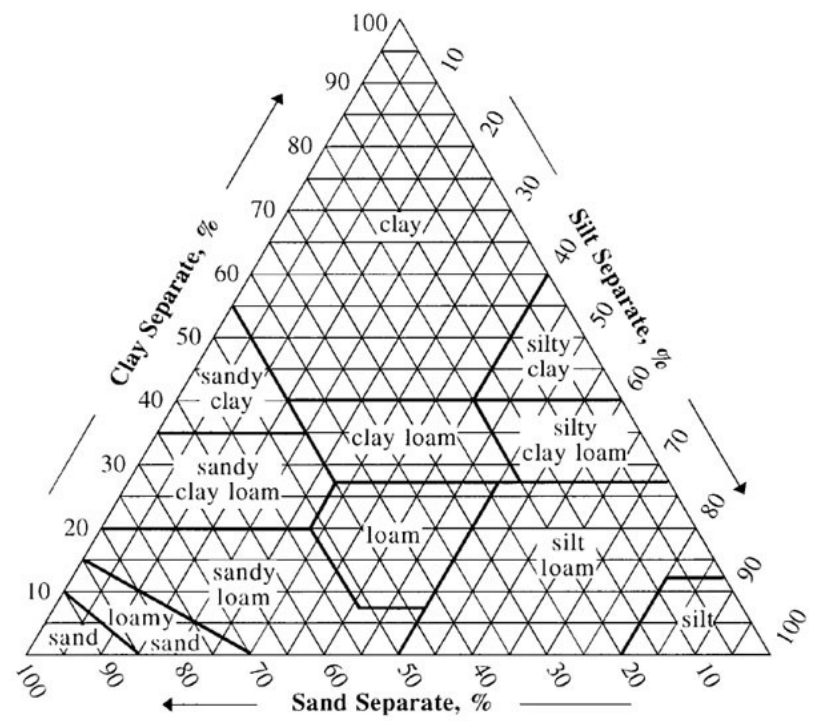

Figure 4. The soil textural triangle. Credits: NRCS-USDA

\section{Soil Structure}

Particles that make up soil can be held together in groups called aggregates. These aggregates form in the soil as a result of physical and chemical processes, and how the aggregates occur in the soil profile determines the soil structure. The structure of the soil affects the ability of a soil to transmit and store water and nutrients. Organic matter within the soil can act as a binding agent for soil particles, promoting aggregation and enhancing soil structure. Because most Florida soils have naturally low amounts of organic matter, addition of organic matter amendments, such as compost, can promote the formation of soil aggregates and improve soil structure.

There are multiple types of soil aggregates, including granular, platy, blocky, prismatic and columnar (Figure 5). Some soils do not form aggregates and are considered to be structureless. Almost all of Florida's soils are structureless (single-grain) because they are dominated by sand-sized particles, where soil aggregates rarely form regardless of organic material. Therefore, organic matter additions to soils may not improve soil structure in Florida soils if a healthy soil food web is not present or established. Although it may be difficult to achieve, improving soil structure can provide numerous benefits for a Florida gardener. Increased soil structure enhances the movement of water through the soil profile but can also increase soil water retention, reducing the amount of irrigation needed to grow a healthy landscape. Soil structure also allows roots to penetrate deeper into the soil profile, providing plants access to additional nutrient and water sources in the soil.

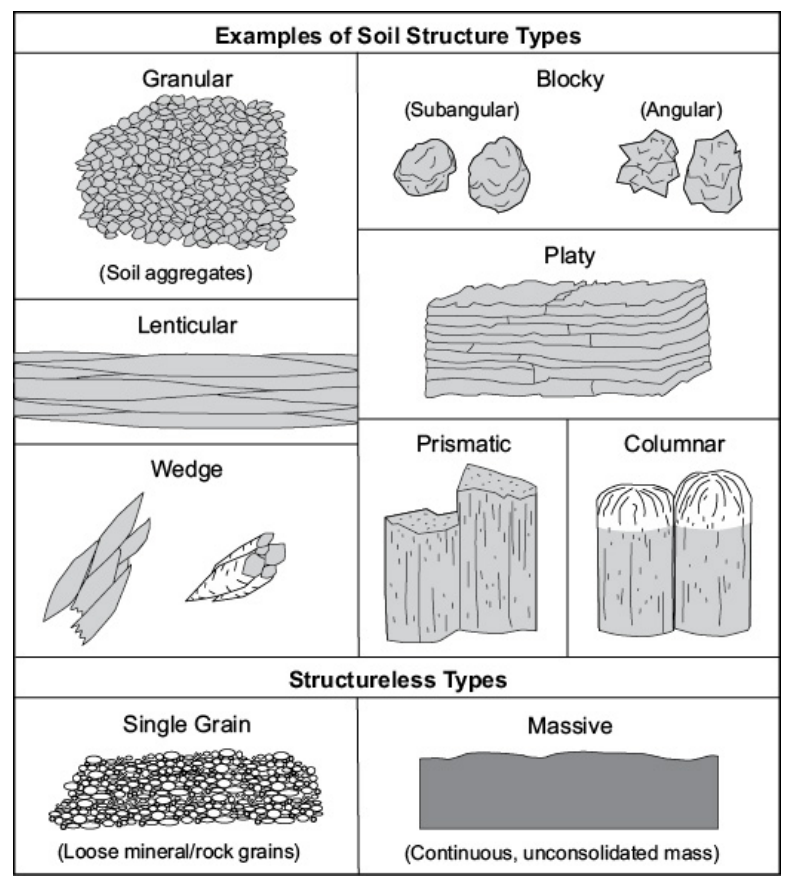

Figure 5. Examples of soil structure types.

Credits: NRCS-USDA 


\section{Soil Density}

Soil bulk density is the mass of air-dried soil per unit volume. Soils with a high proportion of air soil pore space (air pockets within the solid particles of the soil) have low bulk density, and vice versa. Sandy soils with low organic matter, which are common throughout Florida, tend to have higher bulk density than clayey or loamy soils. Typical ranges of bulk density for a variety of soil types are presented in Table 1.

Soil management can impact bulk density. For example, driving heavy machinery over soil during the construction of a home can compact the soil and increase the bulk density (Table 1). In contrast, practices that increase soil organic matter, such as adding a compost amendment to the soil, can reduce bulk density. Soil compaction increases soil bulk density while reducing root penetration and water infiltration. Compaction of soils in residential landscapes can be a major impediment to a healthy landscape. Trying to grow plants in soils with high bulk density is essentially the same as trying to grow them in a brick (Table 1). Compost amendments are one potential tool that the Florida Master Gardener can use to reduce soil bulk density, improve soil structure, and also improve the overall health of the soil ecosystem.

\section{Soil Pores, Infiltration, and Water- Holding Capacity}

The amount of pore space in the soil is determined by the arrangement of soil particles. In highly compacted soils, there is very little pore space. Pore space is higher in soils with high organic matter and defined soil structure. Sandy soils typically have $35 \%-50 \%$ pore space. The ability of soil to hold and transmit water and air is impacted by the amount of pore space in the soil and by the size (diameter) of these pores.

Understanding the structure and pore space of a soil is important because it relates to water- and nutrient-holding capacity of soils. Plants obtain water from the soil through their root system to replace water lost through evapotranspiration. Therefore, soils need to be able to hold this water for use by plants. In addition, soils must be drained well enough to allow for oxygen to reach plant roots to allow for respiration by the plants. Movement of water into soil is called infiltration, and the movement of water within the soil is called percolation. The pore space of a soil controls water infiltration and percolation rates. The amount of water held in a soil is called the soil water content. Saturation is the water content when all soil pores are filled with water. At saturation, soil water content is equal to soil pore space. Field capacity is the soil water content after soil has been saturated and allowed to drain by gravity for $24-48 \mathrm{~h}$. The permanent wilting point of soil is the soil water content when all of the water available to plants has been extracted.

If you think of the soil as a sponge, the sponge is at saturation when water freely drips out. If you let the sponge sit on the counter, the water will stop dripping out after some time, but there will still be water stored within the sponge; this is the field capacity of the soil. If you then picked up the sponge and rung it out to remove as much water as possible, there would still be some water within the sponge that you were unable to remove; this is the wilting point of the soil. The difference between field capacity and permanent wilting point is known as plant available water. This is the amount of water in the soil that does not percolate rapidly through the soil profile but is also not bound up so tightly by soil particles that it is unavailable. Plant available water is strongly influenced by soil texture (Figure 6) and soil structure. Improving the soil structure and increasing the organic matter of the soil will increase the plant available water, reducing irrigation requirements.

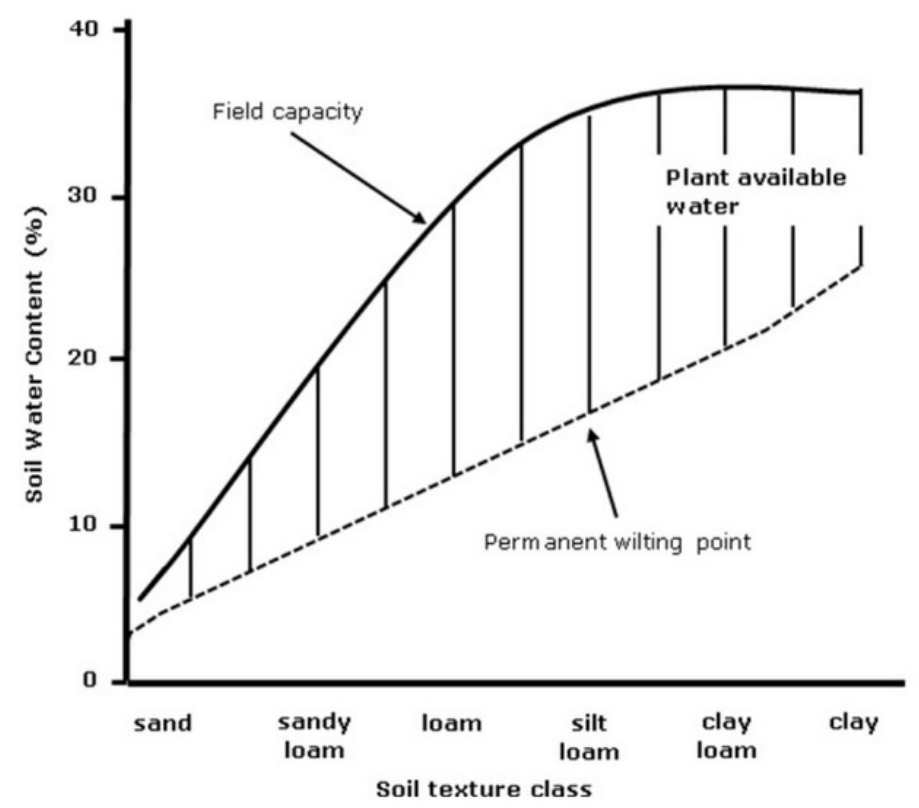

Figure 6. Relationship between soil texture and plant available water. Credits: Nature Education reproduced for non-commercial use in an educational environment

The USDA Natural Resources Conservation Service classified soils into seven natural drainage classes depending on the duration and frequency of wet conditions. The drainage classes are:

Very poorly drained to poorly drained: Water movement is very slow to slow through these soils and artificial drainage is required for most plants to grow. These soils may have 
standing water at the surface or at shallow depths, and they are wet most of the time. These soils typically occur in depressional areas.

Somewhat poorly drained: These soils exhibit periodic wetness at a shallow depth due to a seasonally high water table, a restricting layer, seepage, or high rainfall. Water movement is moderately slow through these soils and artificial drainage may be required.

Moderately well drained: Water movement is slow during some parts of the year. Soils are wet in the root zone for only a short period of the year, potentially restricting root growth. However, these soils do not require artificial drainage in most circumstances.

Well drained: Water movement is good in these soils but not rapid. Adequate water is available to plants throughout the year, but there are no periods where root growth is restricted due to wet conditions, so artificial drainage is unnecessary.

Somewhat excessively drained to excessively drained: Water movement through these soils is rapid to very rapid, and soils do not retain adequate water for plant growth following precipitation. Irrigation is therefore required for acceptable plant growth.

The water-holding and drainage capacity of soils differs throughout Florida. Therefore, it is important for the Master Gardener to understand the soils they are working with and the drainage classification of each soil. To learn more about drainage of Florida soils, see EDIS publication SL441, Agricultural Soils of Florida (http://edis.ifas.ufl.edu/ ss655).

Urban soils are of particular importance to the Master Gardener. They occur throughout Florida in areas where human activities have altered the natural soil landscape. The ability of these soils to hold or transmit water is variable and depends on the level of compaction, the amount of soil covered by hard (impervious) surfaces, and surface crusting. Furthermore, urban soils are often brought in from locations outside of Florida, and the parent material and other soil formation factors may differ from native Florida soils. Urban soils typically have slower infiltration and drainage rates than their natural counterparts. For more information, see EDIS publication SL276, Soils \& Fertilizers for Master Gardeners: Urban Soils and Their Management Issues (http://edis.ifas.ufl.edu/mg456).

\section{Summary}

Soils are a fundamental component of the earth, providing a location for plants to grow roots while also filtering contaminants out of the environment. Soils are made up of mineral material, organic material, microorganisms, air, and water, and the formation of these soils takes thousands of years. Soil formation and development is a function of parent material, climate, topography, biological activity, and time. The physical properties of soil include texture, structure, density, porosity, and water-holding capacity. The ability of water to permeate soils and the ability of soils to retain water are key components in determining what vegetation can grow on soils. Soils are made up of different layers, or horizons, which are formed by different physical and chemical factors occurring at different depths of the soil. Soil taxonomy classifies soils based upon a variety of physical, chemical, and biological properties. Soils in Florida can span a broad gradient of textures, drainage, mineralogy, and organic matter content, depending upon where the soil is located within the state. All of these properties of soils influence water, air, and nutrient movement throughout soils, which can impact plant growth. 
Table 1. Soil bulk densities and potential impacts on root growth based on soil texture. Sources: NRCS-USDA; USGS.

\begin{tabular}{|c|c|c|c|}
\hline Material & $\begin{array}{l}\text { Ideal bulk density for plant } \\
\text { growth }\left(\mathrm{g} / \mathrm{cm}^{3}\right)\end{array}$ & $\begin{array}{l}\text { Bulk densities affecting root } \\
\text { growth }\left(\mathrm{g} / \mathrm{cm}^{3}\right)\end{array}$ & $\begin{array}{c}\text { Bulk densities that restrict root } \\
\text { growth }\left(\mathrm{g} / \mathrm{cm}^{3}\right)\end{array}$ \\
\hline Sands, loamy sands & $<1.60$ & 1.69 & $>1.80$ \\
\hline Sandy loams, loams & $<1.40$ & 1.63 & $>1.80$ \\
\hline Sandy clay loams, clay loams & $<1.40$ & 1.60 & $>1.75$ \\
\hline Silts, silt loams & $<1.40$ & 1.60 & $>1.75$ \\
\hline Silt loams, silty clay loams & $<1.40$ & 1.55 & $>1.65$ \\
\hline Sandy clays, silty clays, clay loams & $<1.10$ & 1.49 & $>1.58$ \\
\hline Clays (>45\% clay) & $<1.10$ & 1.39 & $>1.47$ \\
\hline Red brick & & & 1.90 \\
\hline Limestone & & & $>2.4$ \\
\hline
\end{tabular}

